\title{
Profile of Online Learning in Building Engineering Education Study Program During the COVID-19 Pandemic
}

\author{
Heri Suryaman', Kusnan' ${ }^{2}$, Husni Mubarok ${ }^{3}$ \\ 1,2 Universitas Negeri Surabaya, Surabaya, Indonesia \\ ${ }^{3}$ National Taiwan University of Science and Technology, Taipei, Taiwan
}

\begin{tabular}{|c|c|}
\hline (A) Check for updates open access CC) & DOI : https://doi.org/10.46245/ijorer.v1i2.42 \\
\hline Article Info & ABSTRACT \\
\hline Article history: & This study attempts to discuss the profile of brave learning during the \\
\hline Submitted: June 18, 2020 & COVID-19 pandemic: (1) validity and reliability of instrument; (2) interesting \\
\hline Final Revised: June 23, 2020 & learning for students; (3) implementation of learning; (3) strengths and \\
\hline Accepted: July 11, 2020 & weaknesses of learning; and (4) application that matches the learning profile \\
\hline Published online: July 31, 2020 & and the condition of the existing internet network. The participant of this \\
\hline Keywords: & study were students and lecturers supporting courses in the Building \\
\hline COVID-19 & Engineering Education study program. Data collection uses quantitative and \\
\hline luation & qualitative methods. The questionnaire was given by online to 67 students and \\
\hline Learning implementation & 6 lecturers. The result of this research shows that (1) questionnaire instruments \\
\hline arning profile & have been tested as valid and reliable; (2) online learning is not all interesting; \\
\hline Questio & $\begin{array}{l}\text { (3) online learning has been implemented, but some lecturers have problems } \\
\text { when making corrections, the condition of the internet network in some }\end{array}$ \\
\hline 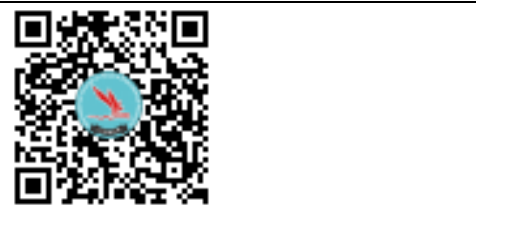 & $\begin{array}{l}\text { regions is not smooth enough to be an obstacle for students to access } \\
\text { applications; (4) using of the application adjusts the online learning profile } \\
\text { and the condition of the internet network in the area. The conclusion reveals } \\
\text { that applications of online learning must be easily accessible, used, interesting, } \\
\text { and needs to be combined with several applications to provide the perfection } \\
\text { of delivery and acceptance of material in teaching and learning activities. }\end{array}$ \\
\hline
\end{tabular}

\section{INTRODUCTION}

Implementation of online learning on undergraduate students of Building Engineering Education during the COVID-19 period was conducted from the 7th meeting to the 15th meeting in the even semester of 2019/2020. Online learning is carried out according to the chancellor's circular about prevention measures for the spread of COVID-19. A variety of online applications are used to support teaching and learning activities. Applications used include E-learning, WhatsApp Group, Google Classroom, Zoom, and other applications. Temporary data from the results of initial observations found some input, suggestions, and obstacles experienced by lecturers and students related to the implementation of online learning. So an evaluation was needed regarding the online learning profile that has been carried out. Supporting factors that influence teaching and learning activities include learning environment, lecturer competence, learning media, curriculum, teaching materials, facilities, and infrastructure. Teacher competency, facilities, and adequate infrastructure become supporting factors of the successful implementation of learning (Indriani \& Atiaturrahmaniah, 2019).

The selection of appropriate and interesting learning media influences students' interest and motivation to learn. The curriculum, teaching materials, facilities, and infrastructure also have a large role to contribute in the learning success. Blended learning evaluation results that are valid, practical, and effective are appropriate for the development of learning (Hamid \& Aras, 2020). Evaluation on 
learning can describe the results that (1) how the learning tools that have been used are categorized as good or not, (2) know the implementation of the learning process, (3) assessment categories, and (4) minimum standards of passing (Tompong \& Jailani, 2019). In the learning process, it is closely related to learning resources and learning experiences. Some examples of learning resources such as human, environment, events, experiences, media, teaching materials, social culture, and so on.

Learning resources can be presented in the form of learning media. Learning experiences in the cognitive, skills, and affective domains are interrelated. These three domains have a positive effect on learning behavior, and support success for improving student learning outcomes (Hill et al., 2019). Problems that arise when online learning is carried out in full without any face-to-face meetings in the classroom between lecturers and students are (1) some students and lecturers are not familiar with online learning, and (2) internet network was not good. And also, some complaints from students related to them were the changing online learning schedules and the implementation of online learning that was not suitable for students. Online learning must be done, therefore to prevent the spread of COVID-19. This forces lecturers to continue to be more creative and innovative in learning. Critics and complaints related to the implementation of online learning from students are used as input to continue to make improvements for the best results. Creativity and innovation are the demands of lecturers in packaging learning, this aims to make students not bored when studying online from home.

Several previous studies related to online learning have been conducted. Students can be interested in learning using the E-learning application (Hogo, 2010). Using simulation models in learning activity gets a better understanding of the material (Pfahl \& Laitenberger, 2004). Students need time to adapt when accepting the innovative learning strategies that used (Savec \& Devetak, 2013). Institutions that have a focus on student learning and career success do not use learning evaluation as a measure of the success of teaching effectiveness (Uttl et al., 2016). Learning modules using electronic media accompanied by discussion can provide an increased understanding of concepts and problem solving (Wong et al., 2017). The use of books or modules can improve student skills so that it can make learning easier (Güven, 2010).

Blended learning that was done well structured can provide benefits for students and teachers, so that learning runs more effectively, student learning outcomes can be improved when compared to traditional learning (Yigit et al., 2014). Applications can be used efficiently to complete student assignments (Alomari et al., 2020). The competence possessed by the lecturer, the learning is done in accordance with the needs of the current student, the process of lecturer-student interaction, and the relevance of the learning resources used must always be updated. The inquiry-based modules presented in online learning can be effective for use (Mamun et al., 2020). Online learning using Elearning can increase student participation, motivation, and learning outcomes (Novocorti et al., 2013). Web-based information technology was presented in an interesting way, equipped with interactive features, and flexible able to motivate students to learn (Vivien et al., 2020). Not all online learning implementations using E-learning can be maximally successful, some are even unsuccessful. However, most studies reveal the positive effects and advantages of e-learning in online learning (Jorge et al., 2018). The characteristics of the learning model must be as needed, sophisticated, have a strong theoretical foundation, and be consistent (Limatahu \& Mubarok, 2020). 


\section{Problem of Research}

The research problem in this study was what the online learning profile was appropriate to be applied to students during the COVID-19 pandemic?

\section{Research Focus}

The focus of this study was to find out what online learning profiles were appropriate to be applied so that learning objectives can be achieved and students were able to take part in teaching and learning activities in online learning easily. It aims to evaluate the online learning profile that has been carried out during the COVID-19 pandemic period in the even semester of the 2019-2020.

\section{RESEARCH METHOD}

The data collection method was carried out using a questionnaire that was given online to students and lecturers supporting the course. The research trial sample used was 67 undergraduate students in the Building Engineering Education, Department of Civil Engineering, Faculty of Engineering, Universitas Negeri Surabaya. Consisting of 2017, 2018, and 2019 students level. Retrieval of data by asking respondents to fill out an evaluation form (Rosenblatt, 2004).

This research activity starts with the preparation of the questionnaire instrument which carried out jointly with the team. Validity and reliability testing has done before the distribution of data collection questionnaires after the instrument has been declared valid and reliable, it can be used for data collection. Testing the validity and reliability can be done using the Alpha Cronbach analysis (Pandiangan et al., 2017).

Collecting data have done using online by google form after lecturing and filling in student grades in the even semester 2019/2020, it was done to students feel free and free without pressure in giving answers in the form of both positive and negative responses to online learning that has been done. Data retrieval can also be done by using qualitative and quantitative variables to analyze user perceptions of technology through questionnaires (Sa et al., 2019). In this study, the results of the questionnaire data from students and lecturers supporting the subjects obtained were further analyzed descriptively quantitative and qualitative.

\section{RESULTS AND DISCUSSION}

Before distributing online questionnaires for data collection, testing the validity and reliability of the instrument was conducted. Validity and reliability testing was used to test the level of validity and how much the measurement results of the questionnaire will be used to collect data on students and lecturers supporting courses in the Building Engineering Education study program. The recapitulation of the validity and reliability test results from the Building Engineering Education student questionnaire has been done which is presented in Table 1. 
Table 1. The validity and reliability of student questionnaires.

\begin{tabular}{|c|c|c|c|c|c|c|c|c|c|}
\hline \multirow{3}{*}{$\begin{array}{l}\text { No } \\
1\end{array}$} & \multirow{3}{*}{$\begin{array}{c}\text { Component } \\
\text { Student self-motivation }\end{array}$} & \multicolumn{4}{|c|}{ Content validity } & \multicolumn{4}{|c|}{ Construct validity } \\
\hline & & \multicolumn{2}{|c|}{$\begin{array}{c}\text { Validity } \\
\left(r_{\alpha}\right)\end{array}$} & \multicolumn{2}{|c|}{$\begin{array}{l}\text { Cronbach's } \\
\text { Alpha (a) }\end{array}$} & \multicolumn{2}{|c|}{ Validity $\left(\mathbf{r}_{\alpha}\right)$} & \multicolumn{2}{|c|}{$\begin{array}{l}\text { Cronbach's } \\
\text { Alpha (a) }\end{array}$} \\
\hline & & .76 & Valid & .94 & Reliable & .78 & Valid & .96 & Reliable \\
\hline 2 & Learning application & .82 & $\mathrm{Va}$ & .92 & Reli & .80 & $\mathrm{~V}$ & .98 & $\mathrm{R}$ \\
\hline 3 & $\begin{array}{l}\text { Learnin } \\
\text { implem }\end{array}$ & .80 & Valid & .95 & Reliable & .84 & $\mathrm{Val}$ & .94 & Reliable \\
\hline 4 & $\begin{array}{l}\text { Evaluation of Learning } \\
\text { Outcomes }\end{array}$ & .74 & Valid & .94 & Reliable & .80 & Valid & .97 & Reliable \\
\hline 5 & Obstacles encountered & .78 & Valid & .96 & Reliable & .78 & Valid & .96 & Reliable \\
\hline
\end{tabular}

The results of the recapitulation of the validity and reliability testing data from the questionnaire supporting lecturers in the fields of education and the field of civil engineering that have been done which is presented in Table 2.

Table 2. The validity and reliability of lecturer questionnaires.

\begin{tabular}{|c|c|c|c|c|c|c|c|c|c|}
\hline \multirow{3}{*}{$\begin{array}{c}\text { No } \\
1\end{array}$} & \multirow{3}{*}{$\begin{array}{l}\text { Component } \\
\text { ng Planning }\end{array}$} & \multicolumn{4}{|c|}{ Content validity } & \multicolumn{4}{|c|}{ Construct validity } \\
\hline & & \multicolumn{2}{|c|}{$\begin{array}{c}\text { Validity } \\
\left(\mathbf{r}_{\mathrm{a}}\right)\end{array}$} & \multicolumn{2}{|c|}{$\begin{array}{l}\text { Cronbach's } \\
\text { Alpha (a) }\end{array}$} & \multicolumn{2}{|c|}{$\begin{array}{l}\text { Validity } \\
\left(\mathrm{r}_{\alpha}\right)\end{array}$} & \multicolumn{2}{|c|}{$\begin{array}{l}\text { Cronbach's } \\
\text { Alpha (a) }\end{array}$} \\
\hline & & .84 & Valid & .96 & Reliable & .86 & Valid & .94 & Reliable \\
\hline 2 & Lear & $.7 \xi_{0}$ & & .9 & & .80 & & & \\
\hline 3 & Lea & .82 & Val & .94 & & .78 & $\mathrm{Va}$ & & \\
\hline 4 & $\begin{array}{l}\text { Evaluation of Learning } \\
\text { Outcomes }\end{array}$ & .77 & & .95 & & .80 & & .97 & \\
\hline 5 & Obstacles encountered & .82 & Valid & .94 & Reliable & .84 & Valid & .96 & Reliable \\
\hline
\end{tabular}

Questionnaire for collecting data on 67 students contains about student selfmotivation, learning applications, learning implementation, evaluation of learning outcomes, and obstacles faced by students during online learning during the COVID-19 pandemic. The recapitulation of data from the questionnaires are presented in Table 3.

Table 3. Data of student questionnaires.

\begin{tabular}{|c|c|c|c|c|c|c|}
\hline \multirow[t]{2}{*}{ No } & Statement & \multicolumn{4}{|c|}{ Response } & $\begin{array}{l}\text { Total } \\
\text { Data }\end{array}$ \\
\hline & Student self-motivation & Agree & Disagree & & & \\
\hline \multirow{3}{*}{$2^{1}$} & Interesting online learning & $49 \%$ & $51 \%$ & & & $100 \%$ \\
\hline & $\begin{array}{l}\text { Online learning is not } \\
\text { boring }\end{array}$ & $28 \%$ & $72 \%$ & & & $100 \%$ \\
\hline & Learning application & E-Learning & WA Group & Zoom & $\begin{array}{l}\text { Google } \\
\text { Classroom }\end{array}$ & \\
\hline \multirow[t]{2}{*}{3} & $\begin{array}{l}\text { Online learning is } \\
\text { effective, interesting, easy } \\
\text { to use, and easy to collect } \\
\text { assignments, midterm, and } \\
\text { final exam }\end{array}$ & $14.16 \%$ & $26.43 \%$ & $23.16 \%$ & $36.23 \%$ & $100 \%$ \\
\hline & $\begin{array}{l}\text { Learning implementation } \\
\text { Easy access and }\end{array}$ & Agree & Disagree & & & \\
\hline 4 & $\begin{array}{l}\text { understanding of the } \\
\text { material }\end{array}$ & $30.06 \%$ & $70 \%$ & & & $100 \%$ \\
\hline
\end{tabular}




\begin{tabular}{|c|c|c|c|c|}
\hline No & Statement & & Response & $\begin{array}{l}\text { Total } \\
\text { Data }\end{array}$ \\
\hline \multirow{3}{*}{$\begin{array}{l}5 \\
6\end{array}$} & Class management is good & $15.95 \%$ & $84.05 \%$ & $100 \%$ \\
\hline & $\begin{array}{l}\text { Media and methods are } \\
\text { appropriate }\end{array}$ & $53.98 \%$ & $46.02 \%$ & $100 \%$ \\
\hline & $\begin{array}{l}\text { Evaluation of learning } \\
\text { outcomes }\end{array}$ & Agree & Disagree & \\
\hline 7 & Easy to do the exercise & $23 \%$ & $77 \%$ & $100 \%$ \\
\hline 8 & Assessment is appropriate & $44 \%$ & $56 \%$ & $100 \%$ \\
\hline 9 & $\begin{array}{l}\text { Learning outcomes } \\
\text { increase }\end{array}$ & $16 \%$ & $84 \%$ & $100 \%$ \\
\hline 10 & $\begin{array}{l}\text { There is feedback from the } \\
\text { lecturer }\end{array}$ & $40 \%$ & $60 \%$ & $100 \%$ \\
\hline & Obstacles encountered & Agree & Disagree & \\
\hline 11 & $\begin{array}{l}\text { Constrained internet } \\
\text { network }\end{array}$ & $85 \%$ & $15 \%$ & $100 \%$ \\
\hline 12 & $\begin{array}{l}\text { Cost of data packages is } \\
\text { expensive }\end{array}$ & $89 \%$ & $11 \%$ & $100 \%$ \\
\hline 13 & $\begin{array}{l}\text { The device does not } \\
\text { support }\end{array}$ & $55 \%$ & $45 \%$ & $100 \%$ \\
\hline
\end{tabular}

Student self motivation towards online learning which was considered interesting and not boring is presented in Figure 1.

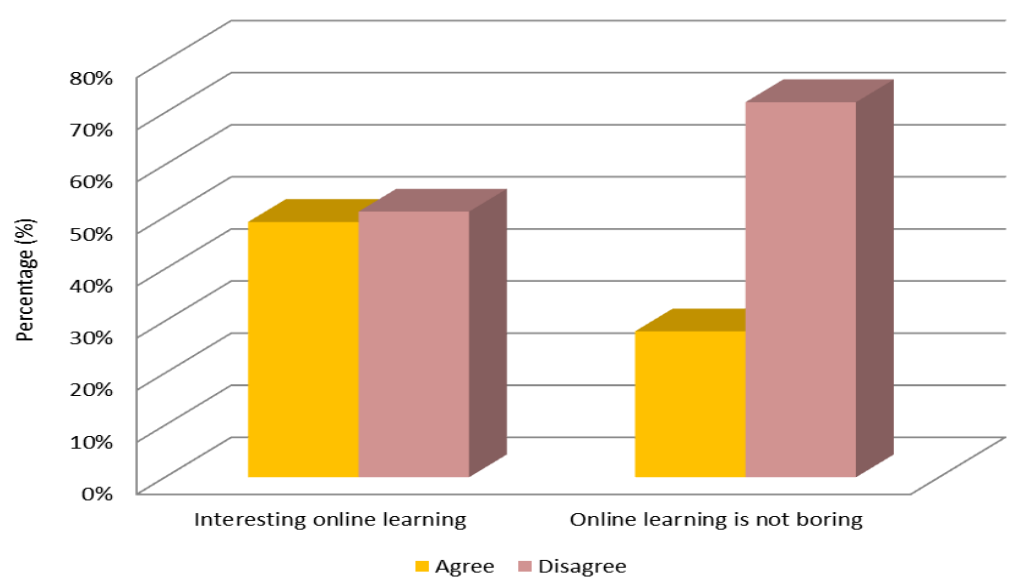

Figure 1. Student self-motivation.

Online learning for students has been effective, interesting, easy to use, and convenience for the collection of assignments, midterm and final exam is presented in Figure 2. 


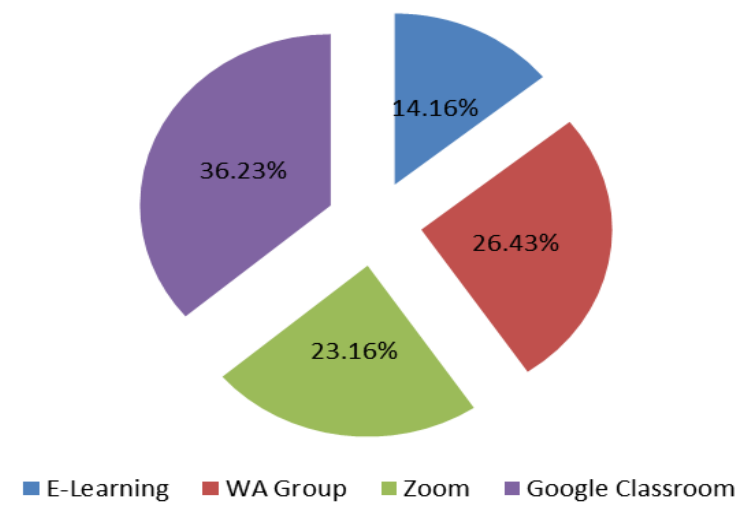

Figure 2. Online learning application for students.

Implementation of online learning was easy for students to access, easy in understanding the material provided by lecturers, classroom management was good, media suitability and methods are presented in Figure 3.

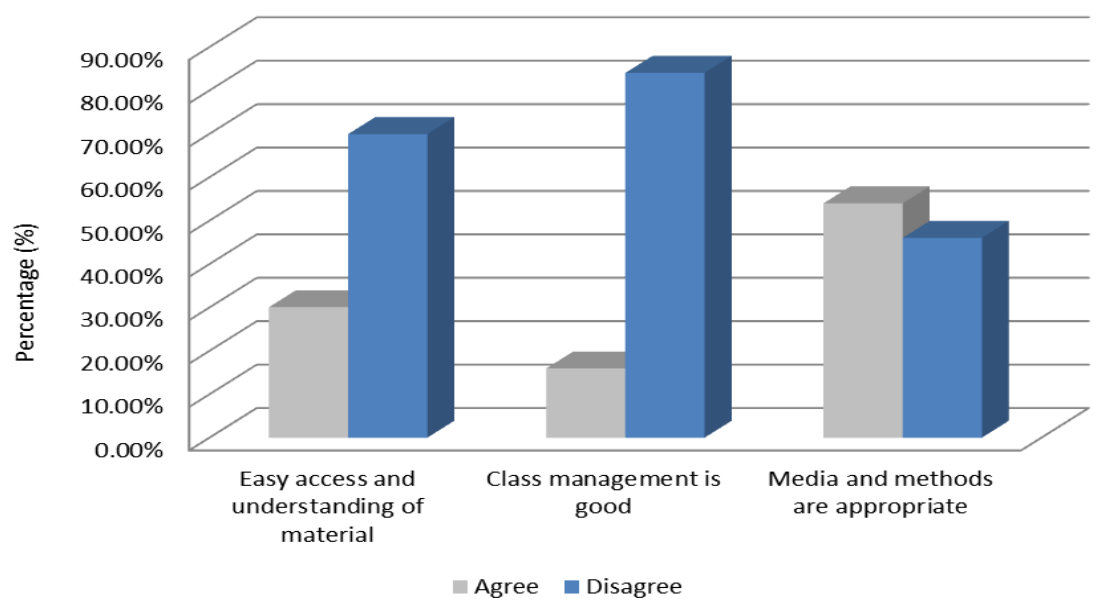

Figure 3. Learning implementation for students.

Evaluation of online learning made it easy to do the exercises, assessments made by the lecturer were appropriate, learning outcomes increased, there was feedback from the lecturer presented in Figure 4.

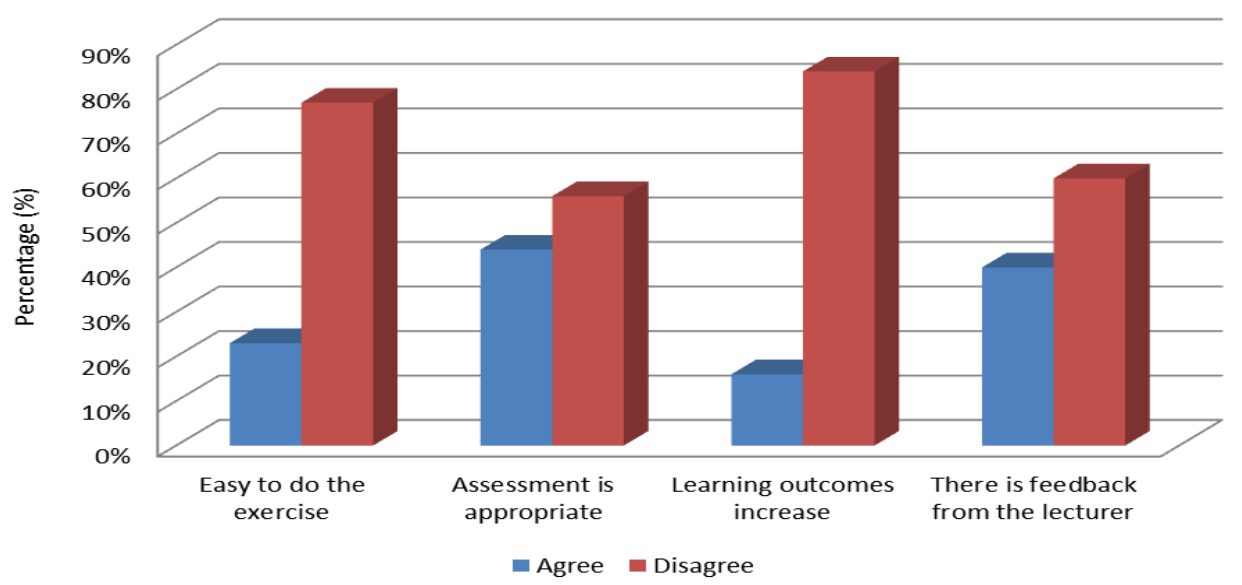

Figure 4. Evaluation of learning outcomes for students. 
Obstacles encountered by students during online learning, which were caused by internet network conditions, expensive data package fees, and unsupported devices are presented in Figure 5.

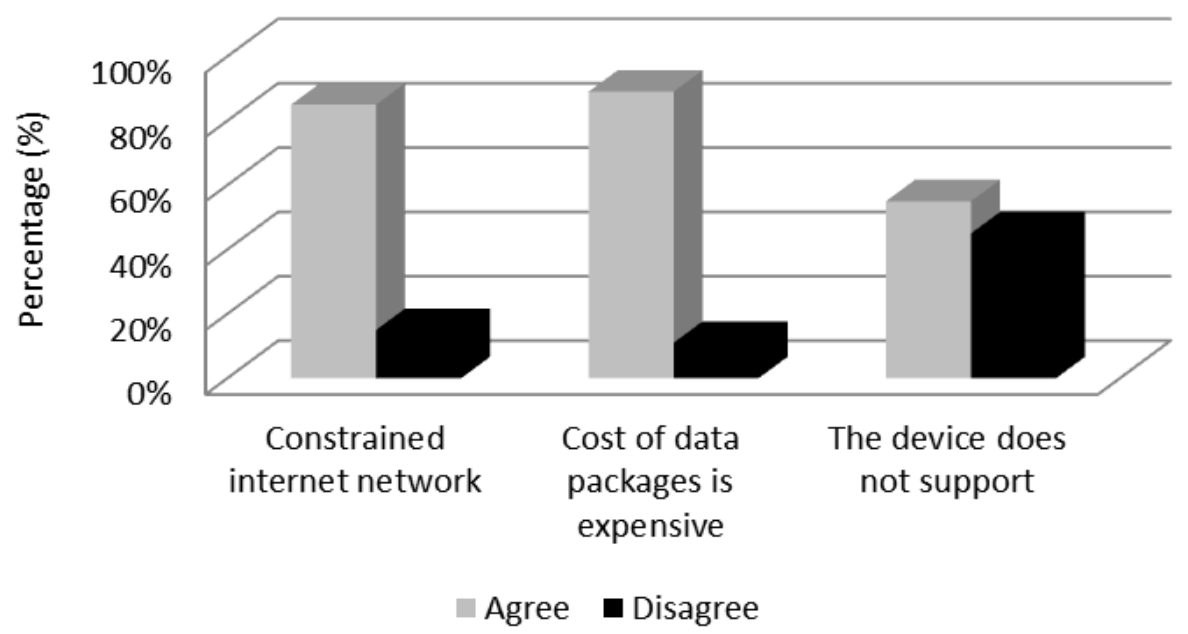

Figure 5. Obstacles encountered by students when studying online.

The data questionnaire of 6 lecturers that supporting education and civil engineering subjects consists of learning planning, learning, training, evaluating learning outcomes, and training discussed by lecturers during bold learning during the COVID-19 pandemic. The results of data recapitulation from the online questionnaire lecturers supporting the courses are presented in Table 4.

Table 4. Data of lecturer questionnaires.

\begin{tabular}{|c|c|c|c|c|c|c|}
\hline No & Statement & \multicolumn{4}{|c|}{ Response } & Total Data \\
\hline & Learning planning & Agree & Disagree & & & \\
\hline 1 & $\begin{array}{l}\text { Lesson plan needs to be } \\
\text { developed }\end{array}$ & $84 \%$ & $16 \%$ & & & $100 \%$ \\
\hline 2 & $\begin{array}{l}\text { Interesting learning material } \\
\text { and resources }\end{array}$ & $69 \%$ & $31 \%$ & & & $100 \%$ \\
\hline 3 & An objective task is prepared & $73 \%$ & $27 \%$ & & & $100 \%$ \\
\hline 4 & Online learning is preferred & $16 \%$ & $84 \%$ & & & $100 \%$ \\
\hline & Learning application & $\begin{array}{c}\text { E- } \\
\text { Learning }\end{array}$ & $\begin{array}{l}\text { WA } \\
\text { Group }\end{array}$ & Zoom & $\begin{array}{l}\text { Google } \\
\text { Classroom }\end{array}$ & \\
\hline 5 & $\begin{array}{l}\text { Effective and attractive } \\
\text { online application, easy to } \\
\text { use for correction of tasks, } \\
\text { midterm, and final exam }\end{array}$ & $36.29 \%$ & $32.74 \%$ & $11.67 \%$ & $19.28 \%$ & $100 \%$ \\
\hline & Learning implementation & Agree & Disagree & & & \\
\hline 6 & Easy to access & $46 \%$ & $54 \%$ & & & $100 \%$ \\
\hline 7 & Easy assignment & $72 \%$ & $28 \%$ & & & $100 \%$ \\
\hline 8 & Easy management of classes & $17 \%$ & $83 \%$ & & & $100 \%$ \\
\hline 9 & $\begin{array}{l}\text { Media and methods are } \\
\text { appropriate }\end{array}$ & $86 \%$ & $14 \%$ & & & $100 \%$ \\
\hline 10 & $\begin{array}{l}\text { Student activity is easily } \\
\text { monitored }\end{array}$ & $26 \%$ & $74 \%$ & & & $100 \%$ \\
\hline & $\begin{array}{l}\text { Evaluation of learning } \\
\text { outcomes }\end{array}$ & Agree & Disagree & & & \\
\hline
\end{tabular}




\begin{tabular}{|c|c|c|c|c|}
\hline No & Statement & & Response & Total Data \\
\hline 11 & Evaluation is easy to do & $47 \%$ & $53 \%$ & $100 \%$ \\
\hline 12 & $\begin{array}{l}\text { Learning evaluation is easy } \\
\text { to control }\end{array}$ & $32 \%$ & $68 \%$ & $100 \%$ \\
\hline 13 & Learning outcomes increase & $12 \%$ & $88 \%$ & $100 \%$ \\
\hline 14 & Give feedback & $74 \%$ & $26 \%$ & $100 \%$ \\
\hline & Obstacles encountered & Agree & Disagree & \\
\hline 15 & $\begin{array}{l}\text { Constrained internet } \\
\text { network }\end{array}$ & $72 \%$ & $28 \%$ & $100 \%$ \\
\hline 16 & $\begin{array}{l}\text { Cost of data packages is } \\
\text { expensive }\end{array}$ & $74 \%$ & $26 \%$ & $100 \%$ \\
\hline 17 & Honesty is difficult to judge & $16 \%$ & $84 \%$ & $100 \%$ \\
\hline
\end{tabular}

Lecturer preparation needed more planning to do online learning activities, requires the development of existing semester learning plans, learning materials and resources must be interesting, objective task preparation was required, and online learning is preferably presented in Figure 6.

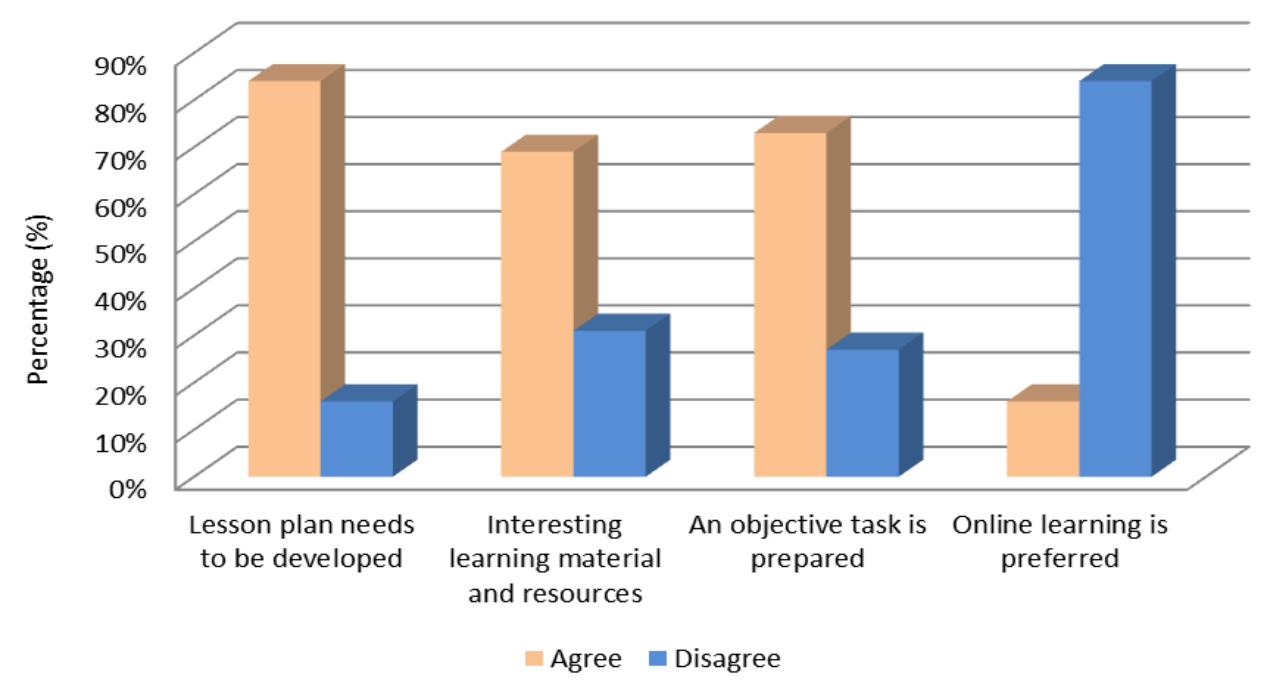

Figure 6. Preparation of learning planning by lecturers.

Online learning for lecturers has been effective and interesting, easy to use to correct assignments, midterm, final exam is presented in Figure 7.

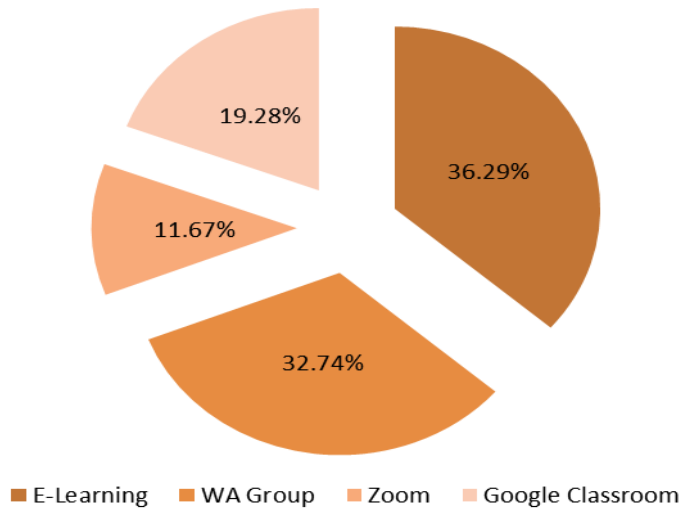


Figure 7. Use of online learning applications for lecturers

Implementation of online learning is easy to access by lecturers, ease in giving assignments, ease of classroom management, appropriateness of media and methods, as well as student activity easily monitored are presented in Figure 8.

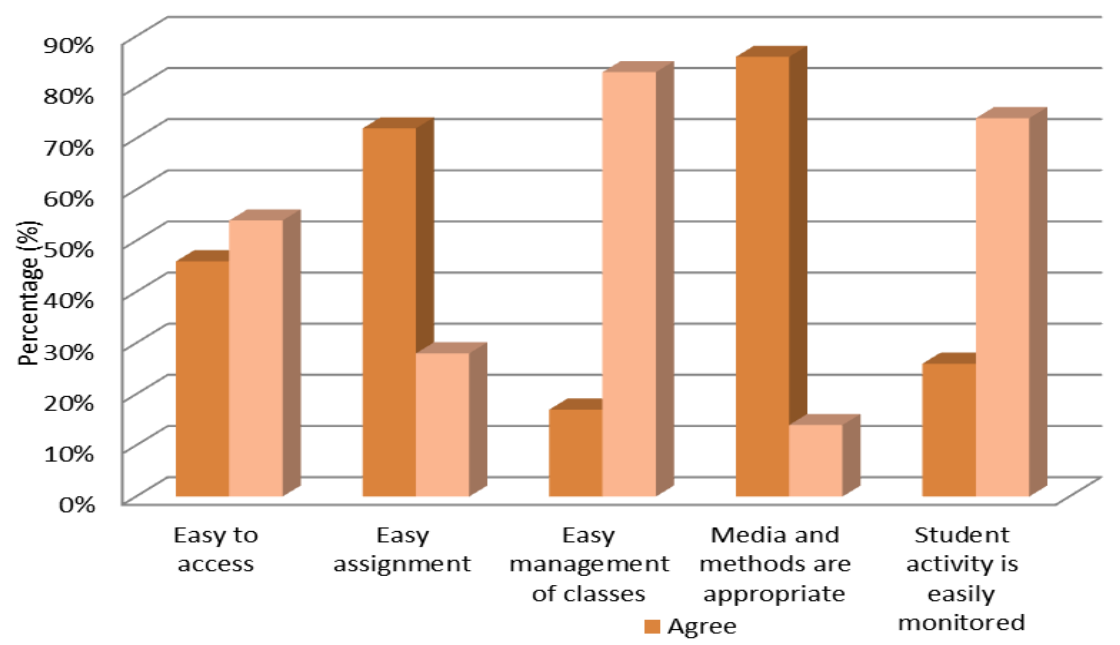

Figure 8. Implementation of online learning for lecturers.

Online learning evaluations were easy to do, learning evaluations were easy to control, student learning outcomes improve, and lecturers have provided feedback presented in Figure 9.

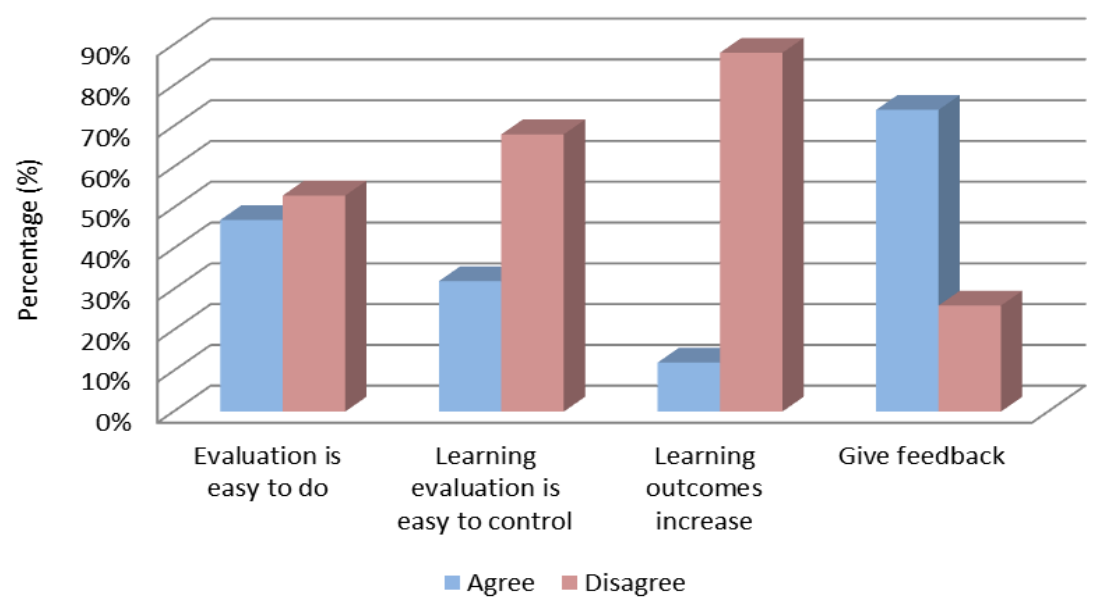

Figure 9. Evaluation of student learning outcomes by lecturers.

Constraints faced by lecturers during online learning, which caused by internet network conditions, expensive data package fees, and difficulties in assessing student honesty are presented in Figure 10. 


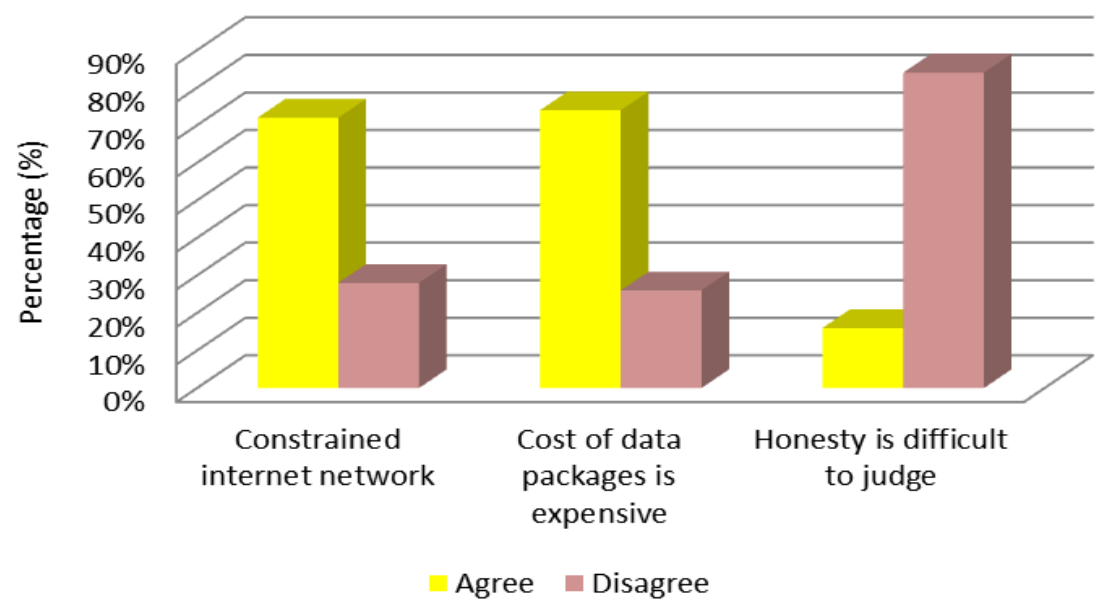

Figure 10. Obstacles encountered by lecturers when studying online.

This online learning research was supported by several previous studies, in which students can be interested when accessing E-learning learning (Hogo, 2010), simulation model learning was able to make the understanding of material obtained by students better (Pfahl \& Laitenberger, 2004), Learning modules presented in electronic media combined with discussion methods were able to improve concept understanding and problem solving (Wong et al., 2017), the application of good blended learning can run more effectively (Yigit et al., 2014), the use of inquiry-based modules in online learning was more effective (Mamun et al., 2020), online learning using E-learning can increase participation, motivation, and learning outcomes (Novo-corti et al., 2013), Web-based information technology that was presented interesting, interactive features, and flexible able to motivate to learn (Vivien et al., 2020), and the implementation of online learning using E-learning has not been able to succeed optimally, it could even be unsuccessful, although most other studies have praised, and implemented e-learning because it has many advantages (Jorge et al., 2018).

The implementation of learning using E-Learning applications in the education system continues to develop, the application of technology using IT has been developed as a substitute for traditional learning (Khan \& Alotaibi, 2020). Learning implementation with E-learning using the google classroom application was recommended because it can increase interest in learning (Ansong-gyimah, 2020). There was an increase in the learning performance of students when using virtual learning (Al-azawei \& Al-masoudy, 2020). One of the solutions offered to overcome the weaknesses that arise from the implementation of problem-based learning, that was needed a form of innovative learning development so that Blended Web Mobile learning was integrated with the Hybrid Learning model and the problem-based learning model that was supported by the use of the MoLearn application (Prahani et al., 2020). Integration of the use of cellular-based technology for learning E-learning can provide positive responses, ease of learning material, and can improve the skills (Elsofany et al., 2020). E-learning was felt by users to be very useful if it was able to meet the quality of the appropriate content, support learning activities, proper assessment, and ease of accessing the learning system were fulfilled (Rutter \& Smith, 2019). Educators must provide information related to how to access learning content through a blended learning system, provide usefully, latest, and interesting content for users (Rutter \& Smith, 2019). 
The use of mobile learning applications can improve academic performance and provide increased collaboration between students (Blilat \& Ibriz, 2020). Appropriate learning innovations were able to foster independence and self-confidence, the impact of implementing online learning made students more actively communicating in online classes, students become enthusiastic, actively participate, and more confident (Tubagus \& Muslim, 2020). The implementation of learning using this platform can be more interactive and can be used in other fields of education (Hazim, 2020). Universitas Negeri Surabaya has been an online learning application in the form of Vi-learning. This application has a variety of features that are easy to use. This application access was lightweight, can be accessed not necessarily at that time if the lecturer has allowed the settings. The material can be accessed or downloaded beforehand and the collection of tasks was left submitted. This application was able to accommodate students who have been programmed according to the schedule. The weakness of this application there was no video call menu.

Whatsapp group is the application that easiest to use, efficient, and the use of data packages needed to access it is also not too heavy. This application is a social media that is familiar to the majority of students. The weakness of this application is the use of video calls in classroom learning still limited, can not be used for large classes, chat, and documents are more dominant in the use of this application in learning. Google Classroom was able to improve student writing performance and skills, positive responses were shown by students because of the ease of use, and application access (Albashtawi et al., 2020). Google classroom was more effective and has a positive influence on behavioral intentions to learn (Al-maroof \& Al-emran, 2018). Learning using Google Classroom can provide an attractive appearance so that for most students they feel increasingly interested in presenting material with this application. Access to learning is easy because it is website based. The preparation needed in this learning is more in the preparation of the class, for older lecturers, it becomes an obstacle because they are not familiar with this application. Complaints delivered by students, learning to use the zoom application if accessed from rural areas with the condition of the internet network is not smooth so the main obstacle for them to follow online learning, even to the point where there are students who have to move to other locations to obtain a good internet network. The advantage felt by students when using the zoom application media is that learning becomes more interesting and the ease of receiving material delivered by lecturers. This application can accommodate online students directly simultaneously with lecturers in large classes. Being able to display presentations both by lecturers' presentations and exercises in the form of student skills tests can also be displayed.

After testing the questionnaire, the results are obtained that the questionnaire was valid and reliable so that it can be used in data collection. Based on the results of the questionnaire from the data collected online learning that has been done shows that online learning is not all interesting for most students, so that makes students get bored quickly. Besides, online learning must be easy to use to receive materials, gathering tasks must also be easy to do, making it easy to do exercises, easy to do question and answer interactions, easy to conduct discussions during learning activities. Online learning has been implemented starting from meeting 7 to meeting 15, but some lecturers have problems when making corrections because they have to download these files one by one. The advantages provided by the use of online learning, namely the 
ease of being able to be accessed from any place as long as it can still be connected to the internet network. Weaknesses of the use of online learning, i.e. in certain applications require a strong network signal in accessing and using it, so it becomes an obstacle for them to access from rural areas with poor internet connection network conditions.

The results of filling out the questionnaire showed that students could not be sure there was an increase in learning outcomes after participating in online learning. Lecturers also cannot be sure that the work that has been collected in the original work of students. The selection of applications used must be in accordance with the online learning profile and under the characteristics of the course so it needs to be managed nicely interesting and not boring. Alternative solutions offered for online learning in the Building Engineering Education study program, are (1) it is better to use a lightweight application that is easily accessed by the internet, if teaching and learning activities require tutorials in learning to be made in the form of videos that can be downloaded, so students do not need to be online directly during learning; (2) hands-on training using the video call application is still needed to check the student's original abilities, but the tests are conducted individually rather than in a large online class; and (3) the use of online learning applications should be combined from several applications to make it interesting and not boring.

\section{CONCLUSIONS}

The conclusions obtained based on the results and discussion, are: (1) The questionnaires used was valid and reliable; (2) online learning was not all interesting, learning has not interesting made students get bored easily, online learning must be easy to use to receive delivery of material from lecturers, gathering assignments was easy to do, easy to do exercises, easy to do question and answer interactions discussion activities during learning activities; (3) online learning has been implemented, but some lecturers have problems when making corrections, the advantage of online learning is can accessed anywhere as long as it is connected to the internet, the weaknesses of online learning in certain applications require strong network signals, so that sometimes it becomes an obstacle to access for students who live in rural areas with substandard internet connection conditions, student work cannot be believed to be able to measure whether there is an increase in learning outcomes; (4) the use of the application adjusts the online learning profile and the condition of the internet network in the area, the selected online learning application must be in accordance with the course and must be managed as well as possible in order to be interesting and not boring for students. So the online learning application in the building engineering education study program must be easily accessible, easy to use, interesting to use, and needs to be combined with several different applications to provide excellent material delivery by lecturers and acceptance of the material for students in teaching and learning activities. The results obtained from this study are expected to have implications, i.e. (1) as a reference in implementing online learning; (2) increase knowledge, thought contributions, and study material for lecturers who wish to further study related to the implementation of online learning; and (3) online learning is appropriate to be implemented as a preventative measure for the spread of COVID-19. Suggestions for further research, namely: (1) need special instruments to measure student learning outcomes when implementing online learning; and (2) further research 
is needed to assess whether online learning is appropriate if it is implemented for practicum.

\section{ACKNOWLEDGEMENTS}

The research team would like to thank all the leaders at the Faculty of Engineering, Universitas Negeri Surabaya, for providing the opportunity to conduct research related to online learning.

\section{REFERENCES}

Al-azawei, A., \& Al-Masoudy, M.A.A. (2020). Predicting learners' performance in virtual learning environment (VLE) based on demographic, behavioral and engagement antecedents. International Journal of Emerging Technologies in Learning, 15(9), 60-75.

Al-maroof, R.A.S., \& Al-emran, M. (2018). Students Acceptance of google classroom: An exploratory study using PLS-SEM approach. International Journal of Emerging Technologies in Learning, 13(6), 112-123.

Albashtawi, A.H., Bader, K., \& Bataineh, A. (2020). The effectiveness of google classroom among EFL students in jordan: an innovative teaching and learning online platform. International Journal of Emerging Technologies in Learning, 15(11), 7888.

Alomari, H.W., Ramasamy, V., Kiper, J.D., \& Potvin, G. (2020). A User Interface ( UI ) and User eXperience ( UX ) evaluation framework for cyberlearning environments in computer science and software engineering education. Heliyon, 6, e03917.

Ansong-gyimah, K. (2020). Students' perceptions and continuous intention touse elearning systems: The case of google classroom. International Journal of Emerging Technologies in Learning, 15(11), 236-244.

Blilat, A., \& Ibriz, A. (2020). Design and Implementation of P2P Based Mobile App for Collaborative Learning in Higher Education. International Journal of Emerging Technologies in Learning, 14(7), 115-132.

El-sofany, H.F., Science, C., El-haggar, N., \& Arabia, S. (2020). The effectiveness of using mobile learning techniques to improve learning outcomes in higher education. International Journal of Emerging Technologies in Learning, 14(8), 4-18.

Güven, S. (2010). Evaluation of life sciences teachers' books according to teachers' opinions. Procedia Social and Behavioral Sciences, 2, 1914-1918.

Hamid, H., \& Aras, I. (2020). Blended learning in research statistics course at the english education department of Borneo Tarakan. International Journal of Emerging Technologies in Learning, 15(7), 61-73.

Hazim, H. T. (2020). Design and implementation of an e-learning platform using NTIER architecture. International Journal of Emerging Technologies in Learning, 14(6), 171-185.

Hill, J., West, H., Hill, J., \& West, H. (2019). Improving the student learning experience through dialogic feed-forward assessment feed-forward assessment. Assessment $\mathcal{E}$ Evaluation in Higher Education, 45(1), 1-16.

Hogo, M.A. (2010). Applications evaluation of e-learning systems based on fuzzy clustering models and statistical tools. Expert Systems With Applications, 37(10), 6891-6903.

Indriani, F., \& Atiaturrahmaniah. (2019). Evaluation of the implementation of integrative thematic learning: A qualitative research approach phenomenology. 
Jurnal Penelitian Dan Evaluasi Pendidikan, 23(2), 184-196.

Jorge, M.M., Neuhann, F., Barnighausen, T., Jahn, A., Guzek, D., \& Barteit, S. (2018). Evaluation of e-learning for medical education in low- and middle-income countries: A systematic review. Computers \& Education Journal, 145(September 2018), 103726.

Khan, Z.F., \& Alotaibi, S. R. (2020). Design and implementation of a computerized user authentication system for e-Learning. International Journal of Emerging Technologies in Learning, 15(9), 4-18. https:/ / doi.org/https:/ / doi.org/10.3991/ijet.v15i09.12387

Limatahu, I., \& Mubarok, H. (2020). CCDSR learning model: Innovation in physics learning. IJORER: International Journal of Recent Educational Education, 1(1), 19-29.

Mamun, A. Al, Lawrie, G., \& Wright, T. (2020). Instructional design of scaffolded online learning modules for self- directed and inquiry-based learning environments. Computers $\mathcal{E} \quad$ Education, 2019), 103695. https:// doi.org/10.1016/j.compedu.2019.103695

Novo-corti, I., Varela-candamio, L., \& Ramil-díaz, M. (2013). E-learning and face to face mixed methodology: Evaluating effectiveness of e-learning and perceived satisfaction for a microeconomic course using the Moodle platform. Computers in Human Behavior, 29(Juli 2012), 410-415. https://doi.org/10.1016/j.chb.2012.06.006

Pandiangan, P., Sanjaya, I.G.M., \& Jatmiko, B. (2017). The validity and effectiveness of physics independent learning model to improve physics problem solving and selfdirected learning skills of students in open and distance education systems. Journal of Baltic Science Education, 16(5), 651-665.

Pfahl, D., \& Laitenberger, O. (2004). Evaluating the learning effectiveness of using simulations in software project management education: Results from a twice replicated experiment. Information and Software Technology, 46(2), 127-147. https://doi.org/10.1016/S0950-5849(03)00115-0

Prahani, B.K., Jatmiko, B., Hariadi, B., Sunarto, D., Sagirani, T., Amelia, T., \& Lemantara, J. (2020). Blended Web Mobile Learning (BWML) model to improve students ' higher order thinking skills. International Journal of Emerging Technologies in Learning, 15(11), 42-55.

Rosenblatt, M.A. (2004). The educational effectiveness of problem-based learning discussions as evaluated by learner-assessed satisfaction and practice change. Journal of Clinical Anesthesia, 16(Desember 2004), 596-601. https://doi.org/10.1016/j.jclinane.2003.12.015

Rutter, M.J., \& Smith, S. (2019). Extending the technology acceptance model to understand students' use of learning management systems in saudi higher education. International Journal of Emerging Technologies in Learning, 14(3), 4-21.

Sa, A., Filho, D.C., Fantini, W.D.S., Atan, M., Santos, J., \& Moreira, F. (2019). Health student using google classroom: Satisfaction analysis. International Workshop on Learning Technology for Education in Cloud, 1, 58-66. https:/ / doi.org/10.1007/978-3030-20798-4

Savec, V.F., \& Devetak, I. (2013). Evaluating the effectiveness of students' active learning in chemistry. Procedia - Social and Behavioral Sciences, 106, 1113-1121.

Tompong, B.N.K.J., \& Jailani. (2019). An evaluation of mathematics learning program at primary education using countenance stake evaluation model. Jurnal Penelitian Dan Evaluasi Pendidikan, 23(2), 156-169.

Tubagus, M., \& Muslim, S. (2020). Development of Learning Management System- 
Based Blended Learning Model using Claroline in Higher Education. International Journal of Emerging Technologies in Learning, 14(6), 186-194.

Uttl, B., White, C.A., \& Gonzalez, D.W. (2016). Meta-analysis of faculty's teaching effectiveness : Student evaluation of teaching ratings and student learning are not related. Studies in Educational Evaluation, 54, 22-42.

Vivien, X., Chi, Y., Shih, Y., Wang, W., Neo, E., Ang, K., Zhao, S., Sehgal, V., Chi, F., Panneer, U., \& Devi, M. K. (2020). A web-based clinical pedagogy program to enhance registered nurse preceptors' teaching competencies-An innovative process of development and pilot program evaluation. Nurse Education Today, 84, 104215.

Wong, O.Y., Mrt, T., Gillan, C., Mrt, T., Harnett, N., Mrt, T., Li, W., \& Mrt, T. (2017). Evaluating the effectiveness of an electronic learning tool for volumetric imaging training- perceptions of radiation therapy professionals. Journal of Medical Imaging and Radiation Sciences, 48(4), 370-376. https:/ / doi.org/10.1016/j.jmir.2017.08.005

Yigit, T., Koyun, A., Sinan, A., \& Arda, I. (2014). Evaluation of blended learning approach in computer engineering education. Procedia - Social and Behavioral Sciences, 141, 807-812. https:// doi.org/10.1016/j.sbspro.2014.05.140

\footnotetext{
*Heri Suryaman (Corresponding Author)

Department of Civil Engineering, Faculty of Engineering,

Universitas Negeri Surabaya,

Ketintang, Surabaya, East Java, 60231, Indonesia

Email: herisuryaman@unesa.ac.id
}

\section{Kusnan}

Department of Civil Engineering, Faculty of Engineering,

Universitas Negeri Surabaya,

Ketintang, Surabaya, East Java, 60231, Indonesia

Email: kusnan@unesa.ac.id

\section{Husni Mubarok}

Graduate Institute of Digital Learning and Education

National Taiwan University of Science and Technology, Taipei, Taiwan

No. 43, Section 4, Keelung Rd, Da'an District, Taipei City, Taiwan 106

Email: husnimubarok254@gmail.com 